\title{
Trends, Prospects and Utilizations of Sea Cucumber Fisheries in Malaysia
}

\author{
Syed Zulfaqar ${ }^{1}$, M. Aminur Rahman ${ }^{1 *}$, and Fatimah Md. Yusoff ${ }^{1,2}$
}

\begin{abstract}
The holothurian or sea cucumber is one of the marine resources, which has been used not only as luxury food for certain countries but also as medicines. Because of its' higher nutraceutical and pharmaceutical values, sea cucumber has become one of the most important products and it has high price in international market and thus provide an important employment and income source to the coastal communities in many Pacific island countries including Malaysia. They have been harvested for hundreds of years for trade with Asia and were probably one of the worthy exports from the Indo-Pacific islands. Unfortunately, the increase in demand and price, combined with the development of cash economies and growing coastal populations in many islands, has led to widespread overfishing of the resource across much of this region. There is a high level of interest in adoption of aquaculture and stock enhancement techniques to restore production phases, but different capacity levels require implementation of different techniques. Some Pacific island countries and territories have completed successful research trials of hatchery, nursery and release techniques, and now have capacity to scale up this activity but such types of research are still in the initial stage in Malaysia. Factors that work in favor of successful aquaculture include pristine marine environments, long familiarity with sea cucumbers as a commodity, and traditional marine tenure systems that in some places can provide a basis for management of released sea cucumbers. Currently, the exploitation of sea cucumber turns out to be excessive and disrupts its sustainability. Aquaculture is the best way to prevent this severe problem. The success of sea cucumber culture is very depending on broodstock management, seed availability and suitable food for larvae as well as juvenile along with appropriate grow-out culture techniques under controlled rearing protocols.
\end{abstract}

Keywords - Sea cucumber, Be^che-de-mer, Trends, Prospects, Potentials, Utilizations

\section{TRENDS, PROSPECTS AND UTILIZATIONS}

$\mathrm{H}$ OLOTHURIANS or sea cucumbers (Echinodermata: Holothuroidea) have in these past years received a lot of attentions globally. This is in part due to a growing

\footnotetext{
${ }^{1}$ Laboratory of Marine Biotechnology, Institute of Bioscience, Universiti Putra Malaysia, 43400 UPM Serdang, Selangor, Malaysia

${ }^{2}$ Department of Aquaculture, Faculty of Agriculture, Universiti Putra Malaysia, 43400 UPM Serdang, Selangor, Malaysia

*Corresponding Author's E-mail: aminur1963@gmail.com
}

international market for its be ${ }^{\wedge}$ che-de-mer products, a smokeddried sea cucumber prepared for consumption $[1,2]$. The Southeast Asia represents the global market hotspots for sea cucumbers trade. In 2006, 58\% of global sea cucumbers imports were to Hong Kong with Singapore placed the second [3]. The fisheries status of this species has also recently been on the radar of the United Nations FAO, which recognize sea cucumber as an important global food commodity [8]. The increasing interest in this high-valued marine bioresource can also be attributed to many of the active calls by conservation groups for a proper management and enhancement of the species. Convention on International Trade in Endangered Species of Wild Fauna and Flora (CITES), for example has issued a special report in 2002 that highlights the overexploitation and management issues of these highly exploited marine resources [4]. As such, issues surrounding the sea cucumber industries such as its biodiversity conservation, sustainable fisheries and aquaculture potentials have gained strong attentions, especially by the trading countries in the world.

As a country well known for her biodiversity and strategic location in the Coral Triangle (the earth's storehouse of biological diversity and also recognized as the global centre of marine biodiversity), Malaysia has been positioning herself as an important exporter of the sea cucumber products. How Malaysia positioned herself today is of great interest to many interested parties. This prompted inquiries about the overall trends and prospects of sea cucumbers fisheries in the country. The overview of these aspects will thus be emphasized.

Among the important marine bio-resources in Malaysia, sea cucumbers have been considered as an important part of Malaysia's marine heritage due to their rich biodiversity and commercial value. Several ecological studies have been conducted aimed at documenting the distribution and species richness of sea cucumbers in Malaysia. It is estimated that more than 80 species of sea cucumber are present in Malaysia [5]. The commonly exploited sea cucumbers are from the families Holothuriidae and Stichopodidae of the genus Holothuria, Actinopyga, Bohadscia and Stichopus [6]. In Peninsular Malaysia, Stichopus species or gamat as it is locally known, is an important resource for traditional medicine and nutraceutical industry. Stichopus hermanni (curryfish) and $S$. horrens (warty sea cucumber) are two species that are commonly exploited. Raw products from these species are processed into valuable products such as gamat oil and gamat water, used for wound healing and treating arthritis and ulcers. Different from the Peninsular, sea cucumbers harvest in East Malaysia, primarily in the state of Sabah, are mainly traded as 
be che-de-mer products for direct consumption. Species such as Holothuria scabra and $H$. fuscogilva are among the important harvest in the coastal waters of Sabah.

During the recent years, the over-increasing exploitation has caused the decline of these sea cucumber species in Malaysia. Langkawi Island in the west coast of Peninsular Malaysia once dubbed as city of Gamat, for instance, has recorded a major decline in its $S$. hermanni population [7]. Fishers in Sabah also complaints that harvest has become scarcer and is decreasing in body size [6]. This threat of overexploitation however, is not unique in Malaysia as effective fisheries management of holothurians is largely lacking in many parts of the world [8]. In Sabah, yearly sea cucumber landings remains on average constant with 131 in 2010, 149 in 2011, 136 in 2012, and 284 tonnes in 2013 [9]. Many researches are now going on to explore the aquaculture potential of some high-valued sea cucumber species endemic to Malaysian coral reef $[10,11]$.

Compared to other marine invertebrates, sea cucumber has a lot of potentials and prospects in Malaysia. First is the strong local and neighboring market demand for gamat-related products. Gamat oil, for example, is a household product for majority of Malaysians. Gamat has also become a valueadding ingredient into range of products from toothpaste to cosmetics [12]. On the other hand, in Sabah, potential for effective sea cucumber aquaculture is yet to be explored. The excellent water quality and climate in shores of Sabah has long been recognized as the best habitat for aquaculture [13]. A concerted effort from all stakeholders is much needed to expand Sabah aquaculture resources. Second one is the growing interest and mounting discoveries on the medicinal and nutritional properties of the sea cucumbers. Sea cucumbers have been documented to have valuable nutrients such as Vitamin A, Vitamin B1 (thiamine), Vitamin B2 (riboflavin), Vitamin B3 (niacin) and a number of pharmacological activities including anti-angiogenic, anticancer, anticoagulant, anti-hypertension, anti-inflammatory, antimicrobial, antioxidant, antithrombotic, antitumor and wound healing [11, 14-27]. These high-valued constituents and biologically active compounds along with their numerous biological and medicinal properties mostly support towards the effective exploration and potential utilization of sea cucumbers in producing nutraceutical products and functional foods for human health benefits $[1,2,11,28]$.

\section{CONCLUSION AND RECOMMENDATION}

Preliminary studies on the species abundance and distribution patterns of sea cucumbers in Malaysia show that more than 80 species of sea cucumbers are present throughout Malaysia. However, further studies on morphology and genetics of indigenous sea cucumbers from Malaysia especially, for the undetermined species are required in order to get a better view, knowledge and understanding on the taxonomy, species and speciation mechanisms in these diverged taxa. Furthermore, more molecular work such as microsatellite and phylogenetic analyses incorporating proteincoding regions of mitochondria such as cytochrome $b$ and cytochrome $\mathrm{c}$ oxidase I (COI) as additional molecular approaches are important to verify the present inferences.

Overall, our present investigation highlights the urgent need for better monitoring and reporting of catch and abundance data and proper scientific stock and ecosystem impact assessment to ensure more sustainable harvesting of sea cucumbers. Several sea cucumber exporting countries including Malaysia are still heavily relied on capture fisheries [29]. Mohd and Zahaitun [30] suggested that a few considerations must be addressed, especially issues pertaining to the status of sea cucumbers as protected species and level of exploitation of these resources on the Malaysian coral reef. By looking at the possibility of expanding gamat markets and suitability of Malaysian coast for aquaculture, a synergistic effort of gamat-related products enhancement and sea cucumber aquaculture management will likely to open up Malaysia into new economic opportunity in the Indo-Pacific region to a greater extent.

\section{ACKNOWLEDGMENT}

Grateful thanks and appreciations to Universiti Putra Malaysia (UPM) for providing financial supports through Research Management Centre (RMC) under the Geran Putra (GP-I) grant vide Project No. GPI/2014/9450100 to carry out this work efficiently.

\section{REFERENCES}

[1] Rahman, M.A. 2014a. Global sea cucumber fisheries: their culture potentials, bioactive compounds and sustainable utilizations. International Journal of Advances in Chemical Engineering and Biological Sciences, 1(2): 193-197.

[2] Rahman, M.A., Yusoff. F.M. and Arshad, A. 2015. Sea cucumber fisheries: global status, culture, management and extinction risks. International Journal of Chemical, Environmental and Biological Sciences, 3(4): 344-348.

[3] Anderson, S.C., Flemming, J.M., Watson, R. and Lotze, H.L. 2011. Serial exploitation of global sea cucumber fisheries. Fish and Fisheries, 12: 317-339. http://dx.doi.org/10.1111/j.1467-2979.2010.00397.x

[4] CITES, 2012. Species trade and conservation issues. Trade in Sea Cucumbers in the Families Holothuridae and Stichopodidae. Twelfth meeting of the Conference of the Parties, Santiago, Chile. CoP12 Doc. 45.

[5] Kamarudin, K.R., Rehan, R.A., Hashim, M. and Usup, G. 2010. An update on diversity of sea cucumbers (Echinodermata: Holothuroidea) in Malaysia. Malayan Nature Journal, 62(3): 315-334.

[6] Choo, P.S. 2004. Fisheries, trade and utilization of sea cucumbers in Malaysia. In: Lovatelli, A., Conand, C., Purcell, S., Uthicke, S., Hamel, J.-F., and Mercier, A. (Eds.), Advances in Sea Cucumber Aquaculture and Management. FAO Fisheries Technical Paper No. 463, FAO, Rome, Italy, pp. 57-68.

[7] Baine, M. and Choo, P.S. 1999. Sea cucumber fisheries and trade in Malaysia. In: Baine, M. (Ed.), The Conservation of Sea Cucumbers in Malaysia: Their Taxonomy, Ecology and Trade. Proceedings of an International Conference, 25 February 1999, Department of Agriculture, Kuala Lumpur, Malaysia. Printed and published by Heriot-Watt University, pp. 49-63.

[8] Purcell, S.W. 2010. Managing sea cucumber fisheries with an ecosystem approach. Edited/compiled by Lovatelli, A., Vasconcellos, M. and Yimin. Y.. FAO Fisheries and Aquaculture Technical Paper No. 520, FAO, Rome, Italy, 157 pp.

[9] DOF. 2014. Annual fisheries Statistics 2010-2013. Department of Fisheries (DOF), Malaysia. 
[10] Nurzafirah, M. and Ridzwan, H. 2015. Spawning induction and larval rearing of the sea cucumber Holothuria scabra in Malaysia. SPC Bechede-mer Information Bulletin, 35: 32-36.

[11] Zulfaqar, S. Rahman, M.A. and Yusoff, F.M. 2016. Status, prospects and potentials of sea cucumbers in Malaysia. In: Rahman, M.A. and Maeda, K. (Eds.), Proceedings of the International Conference on Agricultural, Environmental and Civil Engineering (AECE-2016), Emirates Research Publishing, Kuala Lumpur, Malaysia, pp. 87-89.

[12] Purcell, S.W., Choo, P.S., Akamine, J. and Fabinyi, M. 2014. Alternative product forms, consumer packaging and extracted derivatives of tropical sea cucumbers. SPC Beche-de-mer Information Bulletin, 4: 47-52.

[13] Galid, R.S. 1998. Investment Prospects and Potential in the Fisheries Sector in Sabah. Seminar Pembangunan Ekonomi Setempat Dalam Era Globalisasi, Institute Development Studies, 23-24 June 1998, ShangriLa Rasa Ria Resort, Tuaran, Sabah.

[14] Tian, F., Zhang, X., Tong, Y., Yi, Y., Zhang, S., Li, L., Sun, P., Lin, L., Ding, J. 2005. PE, a new sulfated saponin from sea cucumber, exhibits anti-angiogenic and anti-tumor activities in vitro and in vivo. Cancer Biology \& Therapy, 4: 874-882. http://dx.doi.org/10.4161/cbt.4.8.1917

[15] Wijesinghe, W.A.J.P., Jeon, Y. J., Ramasamy, P., Wahid, M.E.A. and Vairappan, C.S. 2013. Anticancer activity and mediation of apoptosis in human HL-60 leukaemia cells by edible sea cucumber (Holothuria edulis) extract. Food Chemistry, 139: 326-331. http://dx.doi.org/10.1016/j.foodchem.2013.01.058

[16] Roginsky, A., Singh, B., Ding, X.Z., Collin, P., Woodward, C., Talamonti, M.S., Bell, R.H. and Adrian, T.E. 2004. Frondanol(R)-A5p from the sea cucumber, Cucumaria frondosa induces cell cycle arrest and apoptosis in pancreatic cancer cells. Pancreas, 29: 335. http://dx.doi.org/10.1097/00006676-200411000-00048

[17] Nagase, H., Enjyoji, K., Minamiguchi, K., Kitazato, K.T., Kitazato, K., Saito, H. and Kato, H. 1995. Depolymerized holothurian glycosaminoglycan with novel anticoagulant actions: Antithrombin III and heparin cofactor II-independent inhibition of factor X activation by factor IXa-factor VIIIa complex and heparin cofactor II-dependent inhibition of thrombin. Blood, 85: 1527-1534.

[18] Chen, S., Xue, C., Yin, L., Tang, Q., Yu, G. and Chai, W. 2011. Comparison of structures and anticoagulant activities of fucosylated chondroitin sulfates from different sea cucumbers. Carbohydrate Polymers, 83: 688-696. http://dx.doi.org/10.1016/j.carbpol.2010.08.040

[19] Hamaguchi, P., Geirsdottir, M., Vrac, A., Kristinsson, H.G., Sveinsdottir, H., Fridjonsson, O.H. and Hreggvidsson, G.O. 2010. In vitro antioxidant and antihypertensive properties of Icelandic sea cucumber (Cucumaria frondosa). Presented at IFT 10 Annual Meeting \& Food Expo, Chicago, IL, USA, 17-20 July 2010; presentation no. $282-04$.

[20] Collin, P.D. 2004. Peptides having anti-cancer and anti-inflammatory activity. United State Patent 6,767,890.

[21] Beauregard, K.A., Truong, N.T., Zhang, H., Lin, W. and Beck, G. 2001. The detection and isolation of a novel antimicrobial peptide from the echinoderm, Cucumaria frondosa. Advances in Experimental Medicine and Biology, 484: 55-62. http://dx.doi.org/10.1007/978-1-4615-1291-2_5

[22] Althunibat, O.Y., Ridzwan, B.H., Taher, M., Jamaludin, M.D., Ikeda, M.A. and Zali, B.I. 2009. In vitro antioxidant and antiproliferative activities of three Malaysian sea cucumber species. European Journal of Scientific Research, 37: 376-387.

[23] Mourao, P.A.S., Guimaraes, B., Mulloy, B., Thomas, S. and Gray, E. 1998. Antithrombotic activity of a fucosylated chondroitin sulphate from echinoderm: sulphated fucose branches on the polysaccharide account for its antithrombotic action. British Journal of Haematology, 101: 647-652. http://dx.doi.org/10.1046/j.1365-2141.1998.00769.x

[24] Zou, Z., Yi, Y., Wu, H., Wu, J., Liaw, C. and Lee, K. 2003. Intercedensides $\mathrm{A}-\mathrm{C}$, three new cytotoxic triterpene glycosides from the sea cucumber Mensamaria intercedens Lampert. Journal of Natural Products, 66: 1055-1060. http://dx.doi.org/10.1021/np030064y

[25] San Miguel-Ruiz, J.E. and García-Arrarás, J.E. 2007. Common cellular events occur during wound healing and organ regeneration in the sea cucumber Holothuria glaberrima. BMC Developmental Biology, 7: 119. http://dx.doi.org/10.1186/1471-213X-7-115

[26] Bordbar, S., Anwar, F. and Saari, N. 2011. High-value components and bioactives from sea cucumbers for functional foods-A review. Marine Drugs, 9: 1761-1805. http://dx.doi.org/10.3390/md9101761

[27] Janakiram, N.B., Mohammed, A. and Rao, C.V. 2015. Sea cucumbers metabolites as potent anti-cancer agents. Marine Drugs, 13: 2909-2923. http://dx.doi.org/10.3390/md13052909

[28] Rahman, M.A. 2014b. Sea cucumbers (Echinodermata: Holothuroidea): their culture potentials, bioactive compounds and effective utilizations. In: Kao, J.C.M. and Rahman, M.A. (Eds.), Proceedings of the International Conference on Advances in Environment, Agriculture \& Medical Sciences (ICAEAM'14), International Academy of Arts, Science \& Technology, Kuala Lumpur, Malaysia, pp. 23-27.

[29] Choo, P.S. 2008. Population status, fisheries and trade of sea cucumbers in Asia. In Toral-Granda, V., Lovatelli, A. and Vasconcellos, M. (Eds.), Sea cucumbers: A Global Review of Fisheries and Trade. FAO Fisheries and Aquaculture Technical Paper No. 516, FAO, Rome, pp. 81-118.

[30] Mohd, N.B. and Zahaitun, M.Z. 2004. Position statement on the inclusion of species of sea cucumber from the families of Holothuridae and Stichopodidae into the Appendices of the Convention on International Trade in Endangered Species of Wild Fauna and Flora (Cites). Maritime Institute of Malaysia (MIMA), 1-5. 